\title{
CURRENT STATUS OF BROOMRAPE (Orobanche cumana Wallr.) IN SERBIA
}

\author{
Dedić, B. , Lačok, N., Tančić, S., Dušanić, N., Jocić, S.
}

Institute of Field and Vegetable Crops, Oil Crops Department, 21000 Novi Sad, Serbia

Received: July 15, 2009

Accepted: November 10, 2009

\author{
SUMMARY
}

\begin{abstract}
Broomrape is the major issue in sunflower production in Serbia. Since its first occurrence, the species Orobanche cumana Wallr. had been responsible for considerable yield loss in some areas. In Serbia broomrape is present in the Vojvodina Province. Distribution and virulence groups of parasite are constantly monitored. Only two distinct broomrape populations currently exist in this part of country. Race B is dominant in the south of the Vojvodina Province and race $\mathrm{E}$ in the north. During 2008, sets of 8 commercial hybrids with different broomrape resistance genes were sown in regions with sunflower production. Hybrids were sown on 34 different locations. Presence of broomrape was confirmed on 6 sites. Occurrence of parasitic plants was not detected on cultivars resistant to race $\mathrm{E}$. Sunflower fields in regions where broomrape was not previously detected, were surveyed. The survey revealed occurrence of broomrapes in new regions. Infested areas are located in Bor County near the state border with Romania and Bulgaria.
\end{abstract}

Key words: broomrape, sunflower, distribution, race

\section{INTRODUCTION}

Broomrapes (Orobanche spp.) are obligate parasitic plants with a wide range of hosts among dicotyledonous species. The broomrape plant is small, from $10-60 \mathrm{~cm}$ tall, best recognized by its yellow to straw-colored stems completely lacking chlorophyll. As they have no chlorophyll, they are totally dependent on other plants for nutrients. Broomrape seeds remain dormant in the soil, and remain viable for 1520 years, until stimulated to germinate by certain compounds produced by living plant roots (Škorić, 1988). Broomrape seedlings put out a root-like growth, which attaches to the roots of nearby hosts. Once attached to a host, the broomrape uses the host's water and nutrients, which causes yield reduction. Parasitized plants exhibit lower shoot dry weight, height, and head diameter (Alcantara et al., 2006).

* Corresponding author: Phone: +381 214898 406; e-mail: boskode@ifvcns.ns.ac.rs 
Broomrape races cause severe damage to sunflower (Helianthus) and various other crops, such as tomato, hop, tobacco, carrot, alfalfa, sugar beet, etc. Therefore, they must be controlled using all available strategies. The use of resistant sunflower cultivars is the most reliable way to fight this parasite, and at the present, the broomrape is controlled mainly by this practice. Both susceptible and resistant sunflower varieties stimulate the germination of Orobanche seeds, but the germ tubes fail to develop after penetration into a resistant host (Eizenberg et al., 2003).

Vranceanu et al. (1980) identified five different races A, B, C, D and E, using differentials with $\mathrm{Or}_{1}$ to $\mathrm{Or}_{5}$ genes. A new race designated as race $\mathrm{F}$ appeared in Spain in 1995 (Alonso et al., 1996). In recent years broomrape was found on cultivars resistant to race $\mathrm{F}$ in Spain and Romania (Molinero-Ruis and Melero-Vara, 2004; Pacureanu Joita et al., 2008). Kaya et al. (2004) reported existence of a race in Turkey, which is possibly more virulent than those present in other countries.

The main areas of broomrape distribution in Europe are Ukraine, South Russia, Hungry and countries from the Mediterranean region and Balkan Peninsula (Shindrova, 1999). Pacureanu Joita et al. (2008) reported that more than $55 \%$ of the sunflower acreage in Romania was infested with broomrape.

In Serbia, sunflowera are parasitized by Orobanche cumana Wallr. According to Aćimović (1998), the broomrape occurred in Serbia in early 1950s. Orobanche cumana has been spreading in the Vojvodina Province during the last 10 years, with dominance of race $\mathrm{E}$. Resistance to race $\mathrm{E}$ was achieved by developing the hybrids Bačvanin, Perun and Šumadinac at Institute of Field and Vegetable Crops in Novi Sad (Škorić and Jocić, 2005). Less dominant, but also present on the territory of Vojvodina, is race B (Mihaljčević, 1996). According to Maširević (2001) the region most endangered by broomrape in Vojvodina is Bačka, the parasite spreading between Bačka Topola and Subotica.

Table 1: Hybrids used in field tests

\begin{tabular}{lc}
\hline Hybrid & $\begin{array}{c}\text { Broomrape } \\
\text { resistance genes }\end{array}$ \\
\hline Baća & $\mathrm{Or}_{5}$ \\
Bačvanin & $\mathrm{Or}_{5}$ \\
Branko & $\mathrm{Or}_{5}$ \\
Velja & $\mathrm{Or}_{4}$ \\
Duško & $\mathrm{Or}_{4}$ \\
NS-H-111 & $\mathrm{Or}_{4}$ \\
Šumadinac & $\mathrm{Or}_{5}$ \\
Sremac & $\mathrm{Or}_{4}$ \\
Sumo 3 & $\mathrm{Or}_{4}$ \\
Sumo 1 PR & $\mathrm{Or}_{4}$ \\
\hline
\end{tabular}

The objective of this study was to determine potential increase of broomrape dispersion area and to look for the occurrence of new aggressive populations of broomrape.

\section{MATERIAL AND METHODS}

Field tests Have been conducted which included a total of 8 hybrids. The hybrids were sown in 34 different locations (Table 1). Majority of the locations were in the Vojvodina Province, the main sunflower-growing region in the country. Two additional hybrids, Sumo 3 and Sumo 1 PR, from Institute of Field and Vegetable Crops, Novi Sad, were sown in the location of Šajkaš. 
Table 2: Frequency and intensity scores on sites where broomrape was detected

\begin{tabular}{|c|c|c|c|}
\hline Location & Hybrid & Frequency of attack & Intensity of attack \\
\hline \multirow[t]{8}{*}{ Sombor } & Baća & 0 & 0 \\
\hline & Bačvanin & 0 & 0 \\
\hline & Branko & 0 & 0 \\
\hline & Velja & 0 & 0 \\
\hline & Duško & 0 & 0 \\
\hline & NS-H-111 & 11 & 3.23 \\
\hline & Šumadinac & 0 & 0 \\
\hline & Sremac & 0 & 0 \\
\hline \multirow[t]{4}{*}{ Šajkaš } & Šumadinac & 0 & 0 \\
\hline & Sremac & 0 & 0 \\
\hline & Sumo 3 & 0,33 & 3 \\
\hline & Sumo 1 PR & 4,67 & 2.36 \\
\hline \multirow[t]{8}{*}{ Perlez } & Baća & 0 & 0 \\
\hline & Bačvanin & 0 & 0 \\
\hline & Branko & 0 & 0 \\
\hline & Velja & 3 & 7 \\
\hline & Duško & 0 & 0 \\
\hline & NS-H-111 & 6.33 & 2.79 \\
\hline & Šumadinac & 0 & 0 \\
\hline & Sremac & 1.67 & 5.33 \\
\hline \multirow[t]{8}{*}{ Lukićevo } & Baća & 0 & 0 \\
\hline & Bačvanin & 0 & 0 \\
\hline & Branko & 0 & 0 \\
\hline & Velja & 0.33 & 1 \\
\hline & Duško & 0 & 0 \\
\hline & NS-H-111 & 0.66 & 1.5 \\
\hline & Šumadinac & 0 & 0 \\
\hline & Sremac & 0 & 0 \\
\hline \multirow[t]{8}{*}{ Mokrin } & Baća & 0 & 0 \\
\hline & Bačvanin & 0 & 0 \\
\hline & Branko & 0 & 0 \\
\hline & Velja & 0 & 0 \\
\hline & Duško & 0 & 0 \\
\hline & NS-H-111 & 6.5 & 7.69 \\
\hline & Šumadinac & 0 & 0 \\
\hline & Sremac & 0 & 0 \\
\hline \multirow[t]{8}{*}{ Bački Petrovac } & Baća & 0 & 0 \\
\hline & Bačvanin & 0 & 0 \\
\hline & Branko & 0 & 0 \\
\hline & Velja & 0 & 0 \\
\hline & Duško & 0 & 0 \\
\hline & NS-H-111 & 0.66 & 1 \\
\hline & Šumadinac & 0 & 0 \\
\hline & Sremac & 0 & 0 \\
\hline
\end{tabular}


Random surveys of sunflower fields were performed in areas with sunflower production, placing emphasis on regions without previous detection of broomrape. Frequency of attack was calculated as number of sunflower plants infested with broomrape, while intensity of attack as average number of broomrape plants per sunflower plant.

\section{RESULTS AND DISCUSSION}

Presence of broomrape was confirmed in 6 out of 34 sites (Table 2). In all locations except Šajkaš broomrape was found on the hybrid NS-H-111. Highest parasite's frequency was recorded on this hybrid in the location of Sombor, where $11 \%$ of sunflower plants were attacked. A low intensity of attack was recorded in all experimental sites. Occurrence of parasitic plants was not detected on the hybrids Baća, Šumadinac, Bačvanin and Banaćanin. These hybrids possess $\mathrm{Or}_{5}$ gene and therefore they are resistant to race $\mathrm{E}$.

The survey of sunflower fields in regions where broomrape was not previously detected revealed that broomrapes expanded to new regions. The infested area is located in Bor County near the state border with Romania and Bulgaria. Highest infestation rates were detected in two fields, with the frequencies of $80.8 \%$ and $98.7 \%$, respectively, and intensities of 7.8 and 9.64 , respectively.

Ever since the first registered occurrence of broomrape in Serbia, its populations were stable with respect to race composition. A major change took place with the occurrence of race $\mathrm{E}$, which forced breeders to accept the new circumstances and and start to work on the improvement of the genetic background of sunflower (Mihaljčević, 1996). Observations presented in this paper show that there were no occurrence of a new race in Serbia, although such races are preset in neighbouring countries. However, the broomrape is spreading to new regions, becoming a limiting factor in achieving high yields in the sunflower production.

\section{CONCLUSIONS}

Broomrape is present in main sunflower-growing regions of our country. We have collected new evidence confirming that Orobanche cumana Wallr. is spreading to new regions in Serbia. In 2008, the broomrape was detected in Bor County in eastern Serbia. Presence of races B and E has been confirmed.

\section{REFERENCES}

Aćimović, M., 1998. Bolesti suncokreta, Naučni institut za ratarstvo i povrtarstvo, Novi Sad, Srbija.pp. 671-693.

Alcantara, E., Morales-Garcia, M., Diaz-Sanchez, J., 2006. Effects of Broomrape Parasitism on Sunflower Plants: Growth, Development and Mineral Nutrition, Journal of plant Nutrition, 29: 1199-1206.

Shindrova, P., 1999. Working Subgroup on Orobanche (Orobanche sp.), Progress report (19971998), Helia, Vol. 22(Special issue): 293-308. 
Eizenberg, H., Plakhine, D., Hershenhorn, J., Kleifeld, Y., Rubin, B., 2003. Resistance to broomrape (Orobanche spp.) in sunflower (Helianthus annuus L.) is temperature dependent. Journal of Experimental Botany 54(385): 1305-1311.

Kaya, Y., Evci, G., Peckan, V., Gucer, T., 2004. Determining new broomrape-infested areas, resistant lines and hybrids in Trakya region of Turkey, Helia 40(27): 211-218.

Škorić, D. (1988): Sunflower breeding, Uljarstvo: 1-90.

Škorić, D. and Jocić, S., 2005. Volovod (Orobanche cumana Wallr.) i mogućnost njegovog suzbijanja genetskim i hemijskim putem. Uljarstvo 36(1-2): 15-22.

Velasco L., Pérez-Vich B., Jan C.C., Fernández-Martínez J.M., 2007. Inheritance of resistance to broomrape (Orobanche cumana Wallr.) race $\mathrm{F}$ in a sunflower line derived from wild sunflower species. Plant Breeding 126: 67-71.

Maširević S., 2001. Širenje volovoda na suncokretu i analiza populacije parazita. Zbornik radova, Naučni Institut za ratarstvo i povrtarstvo Novi Sad, Srbija, 35: 235-241.

Mihaljčević, M., 1996. Volovod (Orobanshe cumana Wallr.) na suncokretu - promene u populaciji. Zbornik radova, Institut za ratarstvo i povrtarstvo, Novi Sad, Jugoslavija, 25: 59-71.

Mihaljčević, M., 1996. Distribution and virulence of Orobanche populations in Yugoslavia. EUCARPIA; Proceedigs of the Symposium on Breeding of Oil and Protein Crops, Zaporozhye, Ukraine pp. 134-137.

Molinero-Ruiz, M.R., Molero-Vara, J.M., 2004. Virulence and aggressiveness of sunflower broomrape (Orobanche cumana Wallr.) populations overcoming the $\mathrm{Or}_{5}$ gene, Proc. $16^{\text {th }}$ Int. Sunflower Conference, North Dakota, USA pp. 165-169.

Pacureanu Joita, M., Raranciuc, S., Procopovici, E., Sava, E., Nastase, D., 2008. The impact of the new races of broomrape (Orobanche cumana Wallr.) parasite in sunflower crop in Romania. Disease Resistance and Pathology. Proc. $17^{\text {th }}$ Int. Sunflower Conference, Córdoba, Spain pp. 225-229.

Vranceanu, A.V., Tudor, V.A., Stoenescu, F.M., Pirvu, N., 1980. Virulence groups of Orobanche cumana Wallr. differential hosts and resistance sources and genes in sunflower, Proc. $9^{\text {th }}$ Int. Sunflower Conference, Torremolinos, Spain pp. 74-80.

\title{
SITUACIÓN ACTUAL DEL JOPO (Orobanche cumana Wallr.) EN SERBIA
}

\author{
RESUMEN
}

El problema más importante de la producción de girasol en Serbia es el jopo. Desde su aparición, las especies de Orobanche cumana Wallr. han sido responsables de la pérdida considerable de rendimientos en algunas áreas. En Serbia, el jopo está presente en la provincia de Vojvodina. La distribución y los grupos de virulencia del parásito son constantemente monitoreados. Actualmente existen sólo dos poblaciones distintas de jopo en esta parte del país. Al sur de la provincia de Vojvodina la raza dominante es la B, al norte la E. Durante 2008 un conjunto de 8 híbridos comerciales, con diferentes genes de resistencia al jopo, fue sembrado en el área de cultivo de girasol. Los híbridos se sembraron en 34 localidades. Se confirmó la presencia del jopo en 6 sitios. No se detectaron plantas parásitas en cultivares resistentes a la raza E. Los lotes de girasol ubicados en regiones donde el jopo no había sido previamente detectado fueron monitoreados. Se reveló la aparición del jopo en una nueva región. Las áreas infestadas se sitúan en la Provincia de Bor, cerca de la frontera con Rumania y Bulgaria. 


\title{
ÉTAT DES LIEUX DE L'Orobanche (Orobanche cumana Wallr.) EN SERBIE
}

\author{
RÉSUMÉ
}

L'Orobanche est un problème majeur pour la production de tournesol en Serbie. Depuis sa première apparition, Orobanche cumana Wallr a été responsable de pertes considérables de rendement dans certains secteurs. En Serbie, l'Orobanche est présente dans la province de Vojvodina. La distribution et la virulence des groupes de parasites sont constamment surveillées.

Seules deux populations distinctes d'Orobanche existent actuellement dans cette partie du pays. La race B est prédominante dans le sud de la province de Vojvodina et la race E dans le nord. En 2008, un lot de 8 hybrides commerciaux avec différents gènes de résistance à l'Orobanche ont été semés dans des régions de production du tournesol dans 34 lieux différents.

La présence d'Orobanche a été confirmée à 6 endroits. Aucune présence de plantes parasites n'a été détectée sur les cultivars résistants à la race $\mathrm{E}$.

Les champs de tournesol ont été surveillés dans les zones où l'Orobanche n'avait pas été détectée précédemment. Cette étude a montré la présence d'Orobanche dans ces zones nouvellement infestées. Celles-ci sont situées dans le comté de Bor, près de la frontière avec la Roumanie et la Bulgarie. 